\title{
REVIEW
}

\section{DNA methylation in schizophrenia: progress and challenges of epigenetic studies}

Masaki Nishioka',2, Miki Bundo², Kiyoto Kasai' and Kazuya Iwamoto*2,3

\begin{abstract}
Schizophrenia is a severe psychiatric disease affecting about $1 \%$ of the world's population, with significant effects on patients and society. Genetic studies have identified several candidate risk genes or genomic regions for schizophrenia, and epidemiological studies have revealed several environmental risk factors. However, the etiology of schizophrenia still remains largely unknown. Epigenetic mechanisms such as DNA methylation and histone modifications can explain the interaction between genetic and environmental factors at the molecular level, and accumulating evidence suggests that such epigenetic alterations are involved in the pathophysiology of schizophrenia. However, replication studies to validate previous findings and investigations of the causality of epigenetic alterations in schizophrenia are needed. Here, we review epigenetic studies of schizophrenia patients using postmortem brains or peripheral tissues, focusing mainly on DNA methylation. We also highlight the recent progress and challenges in characterizing the potentially complex and dynamic patterns of epigenomic variations. Such studies are expected to contribute to our understanding of schizophrenia etiology and should provide novel opportunities for the development of therapeutic drugs.

Keywords DNA methylation, gene-environment interaction $(G \times E)$, hydroxymethylcytosine, psychiatric disease, mental disorder.
\end{abstract}

\section{Schizophrenia: clinical course, epidemiology and pathogenesis}

Schizophrenia is a severe and relatively common psychiatric disease, affecting approximately $1 \%$ of the population

*Corresponding author: kaziwamoto-tky@umin.ac.jp

${ }^{2}$ Department of Molecular Psychiatry, Graduate School of Medicine, The University of Tokyo, Hongo 7-3-1, Bunkyo-ku, Tokyo 1138655, Japan

Full list of author information is available at the end of the article worldwide [1]. Patients with schizophrenia suffer from three categories of symptoms: positive symptoms (for example, auditory hallucinations and paranoia), negative symptoms (for example, anhedonia and social withdrawal) and cognitive impairment. The disease course typically starts with positive symptoms, and then progresses to a chronic stage with negative symptoms and cognitive impairment. Many patients experience the onset of schizophrenia around adolescence and usually need medication for the rest of their lives. The pattern of symptoms differs greatly between individuals, making the characterization of schizophrenia difficult. Consequently, the societal burden of schizophrenia is also significant. The World Health Organization estimated that schizophrenia contributed about $2 \%$ of worldwide disability-adjusted lifeyears [2]. Although various kinds of antipsychotic medications, such as clozapine and haloperidol, and other psychotropic medications, such as valproate (VPA), as well as social services are useful for the alleviation of symptoms, there are no curative therapies. In addition, antipsychotic drugs are supposed to be effective for the treatment of positive symptoms but not for the treatment of other symptoms. Therefore, it is imperative to decipher the etiology of schizophrenia to establish better therapeutic strategies [1].

Schizophrenia is partly a genetic disease, as evidenced by family, twin and adoption studies [3]. Traditionally, the risk of schizophrenia has been estimated to be up to $46 \%$ when both parents have schizophrenia. The concordance rate of monozygotic twins for schizophrenia is $48 \%$ and is always higher than that of dizygotic twins [3]. The fact that not all monozygotic twins are concordant for the onset of schizophrenia suggests that environmental factors are also important. For example, viral infection during the fetal period is a well-known high risk factor for schizophrenia [4]. Greater parental ages at the time of birth [5], reduced nutrition during the fetal period and after birth [6], perinatal abnormalities [7], social stress [8] and other factors [9-12] have also been reported as risk factors (Table 1). Those with a high genetic risk for schizophrenia are thought to be more vulnerable to the environmental factors, a phenomenon known as geneenvironment interaction $(G \times E)$. For example, people 
Table 1. Examples of environmental factors implicated in schizophrenia

\begin{tabular}{lc}
\hline Environmental risk factors & Reference(s) \\
\hline Viral infection during the fetal period & {$[4,13]$} \\
Greater parental ages at the time of birth & {$[5]$} \\
Reduced nutrition during the fetal period and after birth & {$[6]$} \\
Perinatal abnormalities & {$[7]$} \\
Social stress & {$[8]$} \\
Living in urban areas & {$[9]$} \\
Immigration & {$[10]$} \\
Winter/spring birth & {$[11]$} \\
Cannabis use & {$[12]$} \\
\hline
\end{tabular}

with a family history of psychosis are more likely to suffer from schizophrenia if they have experienced viral infection during the fetal period [13].

Numerous family, linkage and case-control genetic association studies have been performed. Genes such as COMT, DTNBP1, NRG1, RGS4, GRM3, G72, PPP3CC, CHRNA7 and PRODH have been relatively well replicated as genetic factors for schizophrenia [14-18]. Largescale genome-wide association studies have also identified replicable genetic risk factors, including the major histocompatibility complex (MHC) region, and genes such as ZNF804A, TCF4, NRGN and MIR137 [19-23]. These main implicated genes and loci are summarized in Table 2.

In addition to these common variants, rare structural variants with large effect size have been identified (Table 2). For example, rare copy number variations (CNVs) in 1q21.1, 15q11.2 and 15q13.3 have been associated with the risk for schizophrenia [24-26]. Increased occurrence of rare CNVs in patients has also been reported [27]. Microdeletion in 22q11.2 [28] and microduplication in 16p11.2 [29] have also been reported as risk factors for schizophrenia. Intriguingly, genes disrupted by rare variants are enriched for neuronal functions such as $N$-methyl-D-aspartate (NMDA) receptor-related postsynaptic signaling [30]. There is no definitive consensus on the genetic risk factors for schizophrenia, but abnormalities in NMDA-receptor-related glutamatergic synaptic transmission have been suggested as a possible mechanism underlying the etiology of schizophrenia at the molecular level. Although many candidate genes and CNV alterations have been identified as genetic risk factors, the shortcomings of these findings include low reproducibility, low risk ratio, low penetrance, and lack of disease specificity. The heterogeneity of schizophrenia may be one reason for these limitations, but other mechanisms such as epigenetics might also underlie this phenomenon [31,32].
Epigenetic modifications are roughly divided into two categories: cytosine and chromatin/histone modifications. In mammals, DNA methylation of cytosine residues occurs on the cytosine of $\mathrm{CpG}$ dinucleotides, catalyzed by DNA methyltransferases (DNMTs). Methyl-CpGbinding protein 2 (MeCP2) and methyl-CpG-binding domain (MBD) proteins can bind to methylated CpG regions [33]. Chromatin conformation changes in response to histone modifications such as acetylation and methylation. Histone acetylation is a major histone modification, and the process is regulated by histone acetyltransferases and histone deacetylases (HDACs). DNA methylation and histone modifications affect gene expression by changing the profiles of proteins that bind to specific DNA regions; for example, the binding profiles of transcription factors to promoter regions. In addition, DNA methylation on the gene body is thought to affect mRNA processing such as alternative splicing [34,35].

Considering that the epigenome can change in response to environmental factors [36], epigenetic alterations could partly explain $\mathrm{G} \times \mathrm{E}$, and therefore could help to explain the etiology of schizophrenia (Figure 1). In this review, we discuss recent studies of epigenetic alterations in schizophrenia using postmortem brains and peripheral tissue samples, focusing mainly on DNA methylation, a critical component of epigenetic regulation. Other forms of epigenetic modification have been reviewed recently [37-40]. We also consider important challenges and future directions in this field.

\section{Epigenetic studies of schizophrenia}

The main findings of epigenetic studies on schizophrenia using human samples are summarized in Table 3 . In analyzing DNA methylation, one of the traditional approaches is bisulfite sequencing. Sodium bisulfite treatment converts unmethylated cytosine to uracil, but does not convert methylated cytosine. Thus, sequencing DNA after bisulfite modification can allow discrimination between methylated and unmethylated cytosine. Other major approaches include utilization of methylationsensitive restriction enzymes, antibodies against methylated cytosine, and methyl-cytosine binding proteins such as MBD1 and MBD2.

\section{Studies using postmortem brain samples}

Postmortem brains are the most important samples for epigenetic research on schizophrenia, but there are many confounding factors in such studies, including terminal condition (that is, the condition of the samples at death, or their 'agonal state'), cause of death and postmortem condition. In addition, demographic factors such as age, gender and medical history may also affect experimental data. The $\mathrm{pH}$ of brain samples, which reflects the agonal state of the subject, is a major factor that affects 
Table 2. Examples of genetic factors implicated in schizophrenia

\begin{tabular}{|c|c|c|c|c|}
\hline $\begin{array}{l}\text { Chromosomal } \\
\text { location }\end{array}$ & $\begin{array}{l}\text { Candidate } \\
\text { gene }\end{array}$ & Encoded protein & Major function & Reference(s) \\
\hline $22 q 11$ & COMT & Catechol-O-methyltransferase & Monoamine metabolism & [14-16] \\
\hline $6 \mathrm{p} 22$ & DTNBP1 & Dystrobrevin binding protein 1 & Organelle biogenesis & {$[15,16]$} \\
\hline $8 p 12$ & NRG1 & Neuregulin 1 & Signal transduction in cell-cell interactions & [14-18] \\
\hline $1 q 23.3$ & RGS4 & Regulator of $\mathrm{G}$ protein signaling 4 & Regulation of $\mathrm{G}$ proteins & {$[15,16]$} \\
\hline $7 q 21.1$ & GRM3 & Metabotropic glutamate receptor 3 & Excitatory glutamatargic neurotransmission & [15] \\
\hline $13 q 34$ & G72 & D-Amino acid oxidase activator & $\begin{array}{l}\text { Degradation of D-serine, involved in NMDA-type } \\
\text { neurotransmission }\end{array}$ & {$[14,15]$} \\
\hline $8 p 21.3$ & PPP3CC & Catalytic subunit of protein phosphatase 3 & Regulation of dopaminergic signal transduction & {$[14,16]$} \\
\hline $15 q 14$ & CHRNA7 & Nicotinic acetylcholine receptor & Cholinergic synaptic transmission & [16] \\
\hline $22 q 11.21$ & PRODH & Proline dehydrogenase (oxidase) 1 & Proline degradation & {$[14,16]$} \\
\hline $6 p 21.3-22.1$ & MHC region & MHC proteins & Crucial parts in immune system & {$[20,21,23]$} \\
\hline $2 q 32.1$ & ZNF804A & Zinc finger protein 804A & Not fully characterized & {$[19,22]$} \\
\hline $18 \mathrm{q} 21.2$ & TCF4 & Transcription factor 4 & Involved in nervous system development & {$[21,23]$} \\
\hline $11 q 24.2$ & NRGN & Neurogranin & Postsynaptic protein kinase pathway & [23] \\
\hline $1 \mathrm{p} 21.3$ & MIR137 & MicroRNA 137 & Not fully characterized & [21] \\
\hline
\end{tabular}

Copy number or structural variants

\begin{tabular}{llcc}
\hline Chromosomal location & Representative genes in the region & Reference(s) \\
\hline $1 q 21.1$ & CHD1L, GPR89B, BCL9, PRKAB2 and others & {$[24-26]$} \\
$15 q 11.2$ & CYFIP1, TUBGCP5, NIPA1, NIPA2 & {$[24]$} \\
$15 q 13.3$ & CHRNA7, KLF13, OTUD7A, TRPM1 and others & {$[24,26]$} \\
$16 p 11.2$ & KCTD13, MAPK3, TAOK2, CDIPT and others & {$[29]$} \\
$22 q 11.2$ & COMT, PRODH, SLC25A1, CLDN5, TBX1 and others & {$[26,28]$} \\
\hline
\end{tabular}

MHC, major histocompatibility complex; NMDA, N-methyl-D-aspartate.

transcriptome analysis [41-43]. However, Ernst et al. [44] reported that the $\mathrm{pH}$ of brain samples has no significant effect on DNA methylation status. Although DNA methylation is thought to be chemically stable, systematic evaluation of the effects of other factors on epigenetic alterations present in postmortem brain samples is necessary. Nevertheless, studies of postmortem brain samples of schizophrenia patients have revealed epigenetic alterations in several genes in specific brain regions, although some findings have not been confirmed by other groups (Table 3 ).

The GABAergic-neuron-expressed genes GAD67 and $R E L N$ have been shown to be underexpressed at both the mRNA and the protein level in postmortem brains from schizophrenia patients [45]. GAD67 encodes an enzyme that catalyzes production of $\gamma$-aminobutyric acid (GABA), which is a major neurotransmitter of inhibitory neurons. Altered GABAergic neurotransmission has been described in schizophrenia, and GABA receptor agonists, mainly categorized as benzodiazepines, are occasionally prescribed to schizophrenia patients to alleviate anxiety or sleep disturbance, as an adjuvant therapy to antipsychotic drugs. RELN encodes an extracellular matrix protein involved in cell positioning and neuronal migration during brain development. GAD67 and RELN underexpression in the prefrontal cortex appears to be correlated with their promoter hypermethylation $[46,47]$. In addition, the gene encoding DNA methyltransferase 1 (DNMT1) was found to be overexpressed in GABAergic interneurons in postmortem brain samples from schizophrenia patients [48]. However, other groups found no correlation between schizophrenia and RELN promoter methylation levels in (pre)frontal cortices $[49,50]$.

COMT has also been identified as a candidate gene in schizophrenia, and encodes catechol-O-methyltransferase, which is involved in dopamine metabolism. Dopamine is thought to be involved in the molecular pathways underpinning positive symptoms, including hallucinations and delusions. This gene is located on $22 \mathrm{q} 11$, and microdeletion of this region has shown strong correlation with schizophrenia [28]. The methylation status of COMT in schizophrenia is controversial. COMT promoter hypomethylation and corresponding COMT mRNA overexpression in left frontal lobes have been 


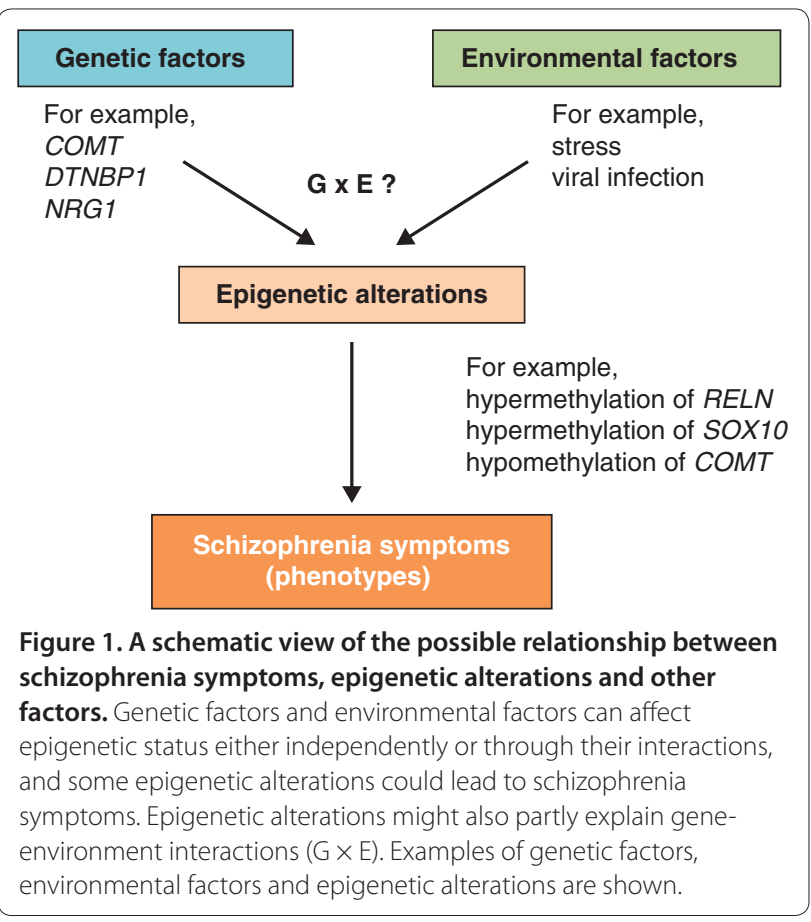

reported [51]. However, another group did not confirm the association between COMT methylation levels and schizophrenia in cerebellum, attributing differences in COMT expression to variation in SNPs [52].

We previously reported that SOX10, which encodes an oligodendrocyte-specific transcription factor, tended to be highly methylated in the prefrontal cortices of schizophrenia patients, and this correlated with the reduced expression of SOX10 and other oligodendrocyte-related genes [53]. SOX10 underexpression can result in oligodendrocyte dysfunction with the downregulation of key oligodendrocyte and myelination genes, which has been observed in studies utilizing postmortem brain samples from schizophrenia patients $[43,54,55]$.

DNA methylation alterations of other genes, such as FOXP2 (which encodes a transcription factor required for language development) [56] and HTR2A (which encodes serotonin receptor $2 \mathrm{~A}$, one of the main target molecules of antipsychotic drugs) [57], have also been reported in postmortem brain samples from schizophrenia patients. Mill et al. [49] first performed comprehensive DNA methylation analysis in postmortem frontal cortices from schizophrenia patients, investigating more than 10,000 CpG islands using CpG-island microarrays. They reported DNA methylation changes in genes related to glutamatergic/GABAergic neurotransmission, brain development, mitochondrial function and stress response.

Altered histone modifications have also been reported in relation to schizophrenia. Akbarian et al. [58] reported that high levels of H3-(methyl)arginine 17 were associated with downregulated expression of metabolic genes in the prefrontal cortex of schizophrenia patients. Huang et al. [59] reported reduced GAD67 expression associated with decreased levels of trimethylated lysine 4 of histone H3 (H3K4me3), a hallmark of gene activation, in prefrontal cortex samples derived from schizophrenia patients, and suggested that chromatin remodeling mechanisms at GABAergic gene promoters might be involved in the pathophysiology of schizophrenia. Tang et al. [60] reported the underexpression of eight genes, including GAD67 and HTR2C (which encodes serotonin receptor $2 \mathrm{C}$ ), associated with hypoacetylation at lysine 9/14 of histone H3 (H3K9K14) in postmortem prefrontal cortex samples from young schizophrenia patients, indicating the transcriptional effect of histone alterations on the investigated genes.

A number of interesting epigenetic alterations of several important genes, possibly related to schizophrenia, have been identified in postmortem brain samples so far. However, most of these studies involved candidate gene approaches, and more comprehensive analyses of epigenetic changes in brains of patients with schizophrenia as well as the effects of confounding factors such as medication remain to be explored.

\section{Studies using blood and other peripheral samples}

In contrast to brain samples, peripheral tissue samples can be obtained from living patients with minimally invasive techniques, and this also enables larger and multiple sample collection. Peripheral tissue samples can also be used in longitudinal studies, in order to investigate the course of disease. Although epigenetic status greatly differs between tissue types, brain samples and peripheral tissue samples could have common epigenetic status in certain genomic regions, and thus could be used to identify epigenetic markers of disease. One study reported that COMT promoter methylation status was nearly identical in brain and blood samples in schizophrenia patients [61]. Dempster et al. [62] reported that methylation alterations in ST6GALNAC1 were observed both in peripheral blood samples and in postmortem brain samples obtained from schizophrenia patients. ST6GALNAC1 encodes $\alpha-N$-acetylgalactosaminide $\alpha$ 2,6 -sialyltransferase 1 , an enzyme that transfers sialic acid to $O$-linked $\mathrm{N}$-acetylgalactosamine residues, but its function has not been fully elucidated. Similarly, studies of bipolar disorder also demonstrated that methylation status at specific CpG sites in SLC6A4 (which encodes a serotonin transporter, one of the main targets of antidepressants) and human leukocyte antigen complex group 9 gene (HCG9, which is located within the MHC class I region) showed a common pattern in brain and blood samples [63,64]. More recently, Davies et al. [65] also reported that DNA methylation differences in blood 
Table 3. Epigenetic alterations in schizophrenia reported in studies using human samples

\begin{tabular}{|c|c|c|c|c|c|}
\hline Sample tissue & Approach & $\begin{array}{l}\text { Number of } \\
\text { samples }\end{array}$ & Main findings & Implicated genes & Reference \\
\hline $\begin{array}{l}\text { Postmortem occipital } \\
\text { cortex and prefrontal } \\
\text { cortex }\end{array}$ & Bisulfite sequencing* & $15 \mathrm{Sz}, 15 \mathrm{CT}$ & Hypermethylation of RELN in Sz & $\begin{array}{l}\text { RELN encodes a protein } \\
\text { related to cell positioning and } \\
\text { neuronal migration during brain } \\
\text { development }\end{array}$ & {$[46]$} \\
\hline $\begin{array}{l}\text { Postmortem prefrontal } \\
\text { cortex }\end{array}$ & Bisulfite sequencing* & $11 \mathrm{Sz}, 12 \mathrm{CT}$ & $\begin{array}{l}\text { Hypermethylation of } \mathrm{SO} \times 10 \text { in } \\
\text { Sz; downregulation of SOX10 } \\
\text { transcription in Sz }\end{array}$ & $\begin{array}{l}\text { SOX10 encodes an } \\
\text { oligodendrocyte-specific } \\
\text { transcription factor }\end{array}$ & {$[53]$} \\
\hline $\begin{array}{l}\text { Postmortem frontal } \\
\text { cortex }\end{array}$ & $\begin{array}{l}\text { Bisulfite sequencing*; } \\
\text { methylation-specific } \\
\text { PCR }\end{array}$ & $35 \mathrm{Sz}, 35 \mathrm{CT}$ & $\begin{array}{l}\text { Hypomethylation of } M B-C O M T \\
\text { promoter in Sz }\end{array}$ & $\begin{array}{l}\text { MB-COMT encodes the } \\
\text { membrane-bound form of } \\
\text { catechol-O-methyltransferase, } \\
\text { which is involved in dopamine } \\
\text { metabolism }\end{array}$ & {$[51]$} \\
\hline $\begin{array}{l}\text { Postmortem frontal } \\
\text { cortex }\end{array}$ & $\begin{array}{l}\text { CpG island microarray; } \\
\text { pyrosequencing after } \\
\text { bisulfite-PCR* }\end{array}$ & $35 \mathrm{Sz}, 35 \mathrm{CT}$ & $\begin{array}{l}\text { Methylation changes in genes } \\
\text { related to glutamatergic/ } \\
\text { GABAergic neurotransmission, } \\
\text { brain development, mitochondrial } \\
\text { function and stress response in Sz }\end{array}$ & $\begin{array}{l}\text { Examples include: NR3B and GRIA2, } \\
\text { both of which are involved in } \\
\text { glutamatergic neurotransmission, } \\
\text { and implicated in the etiology of } \\
\text { schizophrenia }\end{array}$ & {$[49]$} \\
\hline $\begin{array}{l}\text { Postmortem prefrontal } \\
\text { cortex }\end{array}$ & $\begin{array}{l}\text { Pyrosequencing after } \\
\text { bisulfite-PCR* }\end{array}$ & $15 \mathrm{Sz}, 15 \mathrm{CT}$ & $\begin{array}{l}\text { No significant difference in RELN } \\
\text { methylation }\end{array}$ & & {$[50]$} \\
\hline $\begin{array}{l}\text { Postmortem } \\
\text { parahippocampus } \\
\text { gyrus }\end{array}$ & Bisulfite sequencing* & $\begin{array}{l}6 \text { right and } 7 \text { left } \\
\text { hemisphere of Sz; } \\
5 \text { right and } 6 \text { left } \\
\text { hemisphere of CT }\end{array}$ & $\begin{array}{l}\text { Hypermethylation of FOXP2 in left } \\
\text { parahippocampus gyrus in Sz }\end{array}$ & $\begin{array}{l}\text { FOXP2 encodes a transcriptional } \\
\text { factor required for the } \\
\text { development of language }\end{array}$ & {$[56]$} \\
\hline Peripheral blood & Bisulfite sequencing* & $\begin{array}{l}1 \mathrm{MZ} \text { pair } \\
\text { concordant for } \\
\text { Sz; } 1 \mathrm{MZ} \text { pair } \\
\text { discordant for } \mathrm{Sz}\end{array}$ & $\begin{array}{l}\text { SZ twin in a pair discordant } \\
\text { for SZ had more similar DRD2 } \\
\text { methylation profiles to the affected } \\
\text { concordant twin pair than to its } \\
\text { unaffected cotwin }\end{array}$ & $\begin{array}{l}\text { DRD2 encodes the D2 subtype of } \\
\text { the dopamine receptor }\end{array}$ & {$[74]$} \\
\hline Peripheral blood & $\begin{array}{l}\text { High-performance } \\
\text { liquid chromatography }\end{array}$ & $\begin{array}{l}210 \mathrm{Sz} \text { ( } 124 \text { male, } \\
86 \text { female); } 237 \\
\text { CT (108 male, } 129 \\
\text { female) }\end{array}$ & Global hypomethylation in male Sz & & {$[66]$} \\
\hline Peripheral blood & $\begin{array}{l}\text { Radiolabeled }\left[{ }^{3} \mathrm{H}\right] \mathrm{dCTP}- \\
\text { extension assay }\end{array}$ & $28 \mathrm{Sz}, 26 \mathrm{CT}$ & $\begin{array}{l}\text { No difference in global DNA } \\
\text { methylation }\end{array}$ & & {$[68]$} \\
\hline Peripheral blood & Bisulfite sequencing* & $30 \mathrm{Sz}, 30 \mathrm{CT}$ & $\begin{array}{l}\text { Hypermethylation in the } \\
\text { neighborhood of disease- } \\
\text { associated SNP rs } 1816071 \text {; } \\
\text { hypomethylation at three CpG } \\
\text { sites; hypermethylation at four CpG } \\
\text { sites, in GABRB2 in Sz }\end{array}$ & $\begin{array}{l}\text { GABRB2 encodes beta } 2 \text { subunit of } \\
G A B A(A) \text { receptor }\end{array}$ & {$[71]$} \\
\hline Peripheral blood & $\begin{array}{l}\text { High-resolution melt } \\
\text { assay* }^{*}\end{array}$ & $40 \mathrm{Sz}, 67 \mathrm{CT}$ & $\begin{array}{l}\text { Hypermethylation 5HTR1A } \\
\text { promoter in Sz }\end{array}$ & $\begin{array}{l}5 \text { HTR1A encodes serotonin } \\
\text { receptor } 1 \mathrm{~A}\end{array}$ & {$[70]$} \\
\hline Saliva & $\begin{array}{l}\text { Bisulfite sequencing*; } \\
\text { methylation specific } \\
\text { PCR }\end{array}$ & $63 \mathrm{Sz}, 76 \mathrm{CT}$ & $\begin{array}{l}\text { Hypomethylation of T102C SNP in } \\
5 H T R 2 A \text { in Sz }\end{array}$ & $\begin{array}{l}5 H T R 2 A \text { encodes serotonin } \\
\text { receptor } 2 \mathrm{~A}\end{array}$ & {$[72]$} \\
\hline
\end{tabular}


Table 3. Continued

\begin{tabular}{|c|c|c|c|c|c|}
\hline Sample tissue & Approach & $\begin{array}{l}\text { Number of } \\
\text { samples }\end{array}$ & Main findings & Implicated genes & Reference \\
\hline Saliva & $\begin{array}{l}\text { Bisulfite sequencing*; } \\
\text { methylation specific } \\
\text { PCR }\end{array}$ & $63 \mathrm{Sz}, 76 \mathrm{CT}$ & $\begin{array}{l}\text { Hypomethylation of MB-COMT } \\
\text { promoter in Sz }\end{array}$ & $\begin{array}{l}\text { MB-COMT encodes membrane- } \\
\text { bound form of catechol-O- } \\
\text { methyltransferase, which is } \\
\text { involved in dopamine metabolism }\end{array}$ & [73] \\
\hline Peripheral blood & $\begin{array}{l}\text { Bead array (Illumina } \\
\text { Infinium Human- } \\
\text { Methylation27)* }\end{array}$ & $\begin{array}{l}11 \mathrm{MZ} \text { pairs } \\
\text { discordant for } \mathrm{SZ}\end{array}$ & $\begin{array}{l}\text { Hypomethylation of ST6GALNAC1 } \\
\text { promoter in psychosis; PUS3 } \\
\text { is a top-ranked differentially } \\
\text { methylated gene in Sz; differential } \\
\text { methylation in psychological- } \\
\text { disorder-related genes such as } \\
\text { ADAMTS3 and SLC6A3 in Sz }\end{array}$ & $\begin{array}{l}\text { ST6GALNAC1 encodes an enzyme } \\
\text { that transfers sialic acid to } \\
\text { O-linked N-acetylgalactosamine } \\
\text { residues, and PUS3 encodes } \\
\text { pseudouridylate synthase } 3, \\
\text { both of which require further } \\
\text { investigation }\end{array}$ & {$[62]$} \\
\hline Peripheral blood & $\begin{array}{l}\text { Global assay } \\
\text { (restriction enzyme } \\
\text { and pyrosequencing); } \\
\text { pyrosequencing after } \\
\text { bisulfite-PCR* }\end{array}$ & $\begin{array}{l}177 \mathrm{Sz}, 171 \mathrm{CT} ; \\
(\mathrm{S}-\mathrm{COMT}: 47 \mathrm{Sz}, 47 \\
\mathrm{CT} ; \mathrm{SLC6A4:67 \textrm {Sz }} \\
81 \mathrm{CT})\end{array}$ & $\begin{array}{l}\text { Global hypomethylation in Sz } \\
\text { Early-onset-associated lower } \\
\text { global methylation; haloperidol- } \\
\text { associated higher global } \\
\text { methylation; hypermethylation } \\
\text { of S-COMT in Sz; no significant } \\
\text { difference in SLC6A4 methylation }\end{array}$ & $\begin{array}{l}\text { S-COMT encodes the soluble form } \\
\text { of catechol-O-methyltransferase, } \\
\text { which is involved in dopamine } \\
\text { metabolism; SLC6A4 encodes a } \\
\text { serotonin transporter }\end{array}$ & {$[67]$} \\
\hline
\end{tabular}

*The limitation of bisulfite treatment (this approach does not allow precise discrimination between various forms of cytosine modifications).

$\mathrm{CT}$, normal controls; DZ, dizygotic twin; GABA, $\gamma$-aminobutyric acid, MZ, monozygotic twin; SNP, single nucleotide polymorphism, Sz, schizophrenia (patients).

samples and those in postmortem brain samples were well correlated in the investigated genomic regions, indicating the utility of peripheral tissue samples in studying mental disorders. Several studies have reported epigenetic alterations in peripheral samples (including blood or saliva) from schizophrenia patients; however in some cases the findings have not been supported by work from other groups (Table 3).

Leukocyte DNA from schizophrenia patients has been reported to be globally hypomethylated [66,67]. However, another group reported no global methylation differences between schizophrenia patients and controls [68], and others have reported overexpression of DNMT1 and DNMT3A mRNA in peripheral blood samples from schizophrenia patients [69]. Given that DNMT proteins promote DNA methylation, these results seem to be contradictory. Interestingly, Melas et al. [67] reported global hypomethylation, especially in patients with early onset schizophrenia (a severe form of disease) compared with controls, indicating a correlation between disease severity and global methylation status. They also reported hypermethylation of $S$-COMT (which encodes the soluble form of COMT) and no differential methylation of SLC6A4 in peripheral blood cells derived from schizophrenia patients. Other groups have reported hypermethylation of the promoter region of 5HTR1A (which encodes serotonin receptor $1 \mathrm{~A}$ ) in leukocytes [70], and hypermethylation of the region around the schizophrenia-associated SNP (rs1816071) of GABRB2 (which encodes the $\beta_{2}$ subunit of GABA(A) receptor) in leukocytes [71]. Further studies will be needed to understand the patterns of DNA methylation in leukocytes from schizophrenia patients.
Altered DNA methylation has also been observed in saliva samples, including hypomethylation of 5HTR2A [72] (in agreement with a study of postmortem brain samples [57]), and hypomethylation of COMT [73] (in agreement with a study of postmortem brain samples [51]) in saliva from schizophrenia patients.

Studies of peripheral samples from monozygotic twins have also revealed interesting findings. Petronis et al. [74] analyzed DNA methylation in the regulatory region of DRD2 (which encodes the D2 subtype of the dopamine receptor) in lymphocytes derived from two sets of monozygotic twins, one concordant and one discordant for schizophrenia. They reported that the affected twin of the discordant pair was epigenetically more similar to the affected concordant twins than to the unaffected co-twin, by analyses of methylation differences at each CpG site [74]. More recently, Dempster et al. [62] analyzed genomewide DNA methylation status in peripheral blood DNA samples obtained from monozygotic twins discordant for major psychosis, including schizophrenia and bipolar disorder. They found significant DNA hypomethylation in the promoter of ST6GALNAC1 in the affected twins with major psychosis, and this hypomethylation was also observed in independent postmortem brain samples [62].

Recently, Kano et al. [75] reported that olfactory cells of schizophrenia patients exhibited alterations in the expression of several genes, including MGST1 (which encodes microsomal glutathione $S$-transferase 1 ), and alterations in H3K4me3 and trimethylated lysine 27 of histone H3 (H3K27me3), which are hallmarks of gene activation and repression, respectively, in the same genes. The utilization of olfactory cells is advantageous in 
psychiatric research because olfactory cells in olfactory bulbs are thought to share cellular traits with neurons in the brain.

Although the precise mechanisms that affect epigenetic status in peripheral tissue samples and their pathophysiological significance in schizophrenia remain unclear, epigenetic alterations in peripheral tissues are useful for development of potential biomarkers for monitoring disease status. Performing more comprehensive epigenome-scale studies using larger sample sizes would be expected to provide further insights into these mechanisms and to facilitate biomarker identification.

\section{Investigating the epigenetic actions of drugs}

VPA, an HDAC inhibitor and the best-known psychotropic drug targeting epigenetic mechanisms, is often prescribed to schizophrenia patients, especially to affective schizophrenia patients, as an adjuvant to antipsychotic drugs. It has been actively investigated using animal models. Several groups have reported the therapeutic effects of VPA in animal models with schizophrenia-like behavior or with neglected upbringing, which were associated with modifications in DNA methylation or histone acetylation [76-78]. Here, we focus on studies investigating the epigenetic effects of VPA using peripheral samples from schizophrenia patients.

VPA has been reported to induce a significant increase in the levels of acetylated histone $\mathrm{H} 3$ (acH3) and acetylated histone $\mathrm{H} 4 \mathrm{(acH} 4)$ in lymphocytes. The increase in acH3 levels positively correlated with VPA concentration, and the VPA-induced increases in acH3 and acH4 were found to be smaller in schizophrenia patients [79]. More recently, Gavin et al. [80,81] reported reduced baseline acH3 levels and elevated dimethylated lysine 9 of histone H3 levels in lymphocytes obtained from schizophrenia patients, which were less responsive to HDAC inhibitors than controls. They also reported that VPA induced a significant increase in GAD67 mRNA levels, acetylation of H3K9K14, and attachment of acetylated H3K9K14 to the promoter of GAD67 in lymphocytes from human subjects, including schizophrenia patients [82]. Taken together, these findings suggest that histone acetylation may be reduced in several genomic regions in schizophrenia patients, and that VPA treatment can increase the levels of histone acetylation in such genomic regions.

Further studies on VPA and other psychotropic drugs using human peripheral samples are needed to better understand the relationship between the effects of these drugs on epigenetic status and their mechanisms of action.

\section{Variations in the epigenome}

Most of the previous epigenetic studies on schizophrenia have focused on DNA methylation, but recent research has identified other forms of cytosine modification. The physiological and pathophysiological roles and distribution of such newly discovered cytosine modifications are yet to be understood, but it may be necessary to investigate their importance in schizophrenia. Recent research has also revealed the heterogeneity of DNA methylation patterns between tissue types or cell types, and other types of epigenomic variations, for example during development and aging, which represent additional challenges for epigenetic studies on schizophrenia.

\section{Dynamic cytosine modifications in the brain}

DNA methylation had been considered to be chemically stable, but recent research has revealed that cytosine modification is a dynamic process. Recent studies have shown that 5 -hydroxymethylcytosine $(5 \mathrm{hmC})$ is abundant in mammalian brain cells [83] and is converted from 5 -methylcytosine $(5 \mathrm{mC})$ by ten-eleven translocation (TET) proteins [84]. 5hmC might be an intermediate product of active demethylation, although its existence had been considered controversial in mammals $[85,86]$. In addition, several other modifications have been described, including 5-hydroxymethyluracil ( $5 \mathrm{hmU}), 5$-formylcytosine (5fC) and 5-carboxylcytosine (5caC) [85,87-89]. $5 \mathrm{fC}$ and $5 \mathrm{caC}$ might also be intermediate products of demethylation $[88,89]$. The pathways that might be involved in these cytosine modifications are shown in Figure 2.

Previous studies of schizophrenia have not provided definitive results on the presence of $5 \mathrm{mC}$ or $5 \mathrm{hmC}$, partly because conventional bisulfite sequencing cannot discriminate between these forms. Therefore, studies will be required to investigate their distribution and potential pathophysiological roles in schizophrenia using techniques that can distinguish between these cytosine modifications [90-94].

\section{Other variations in the epigenome}

Epigenetic diversity has been reported to accumulate in brain cells, germ cells, peripheral blood cells and other tissues over time [95-97], although the effects of aging on specific epigenetic alterations are unclear. Hernandez et al. [98] reported that DNA methylation tends to increase with chronological age in the human brain. On the other hand, Heyn et al. [99] reported that aged individuals had less genome-wide DNA methylation in peripheral blood leukocytes than newborns. Numata et al. [100] reported that dynamic changes in DNA methylation occur in human prefrontal cortex especially during the prenatal period, typically with prenatal decreases in methylation and postnatal increases in methylation.

Monozygotic twins have the same DNA sequences, except in rare cases such as individual de novo mutations [101]. The epigenomes of monozygotic twins are also 


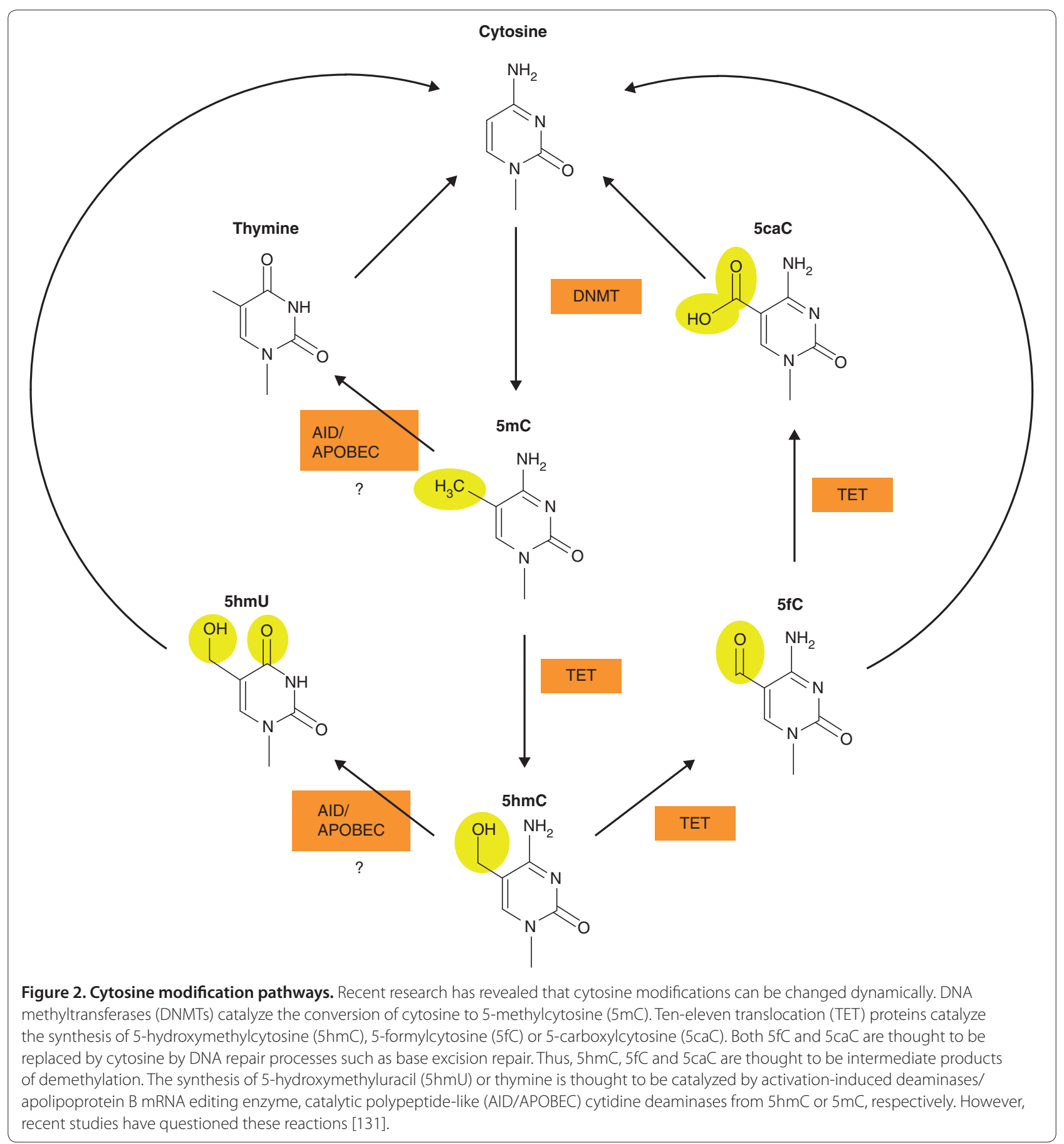

more similar than those of dizygotic twins [102]. Although monozygotic twins are epigenetically indistinguishable early in life, they each experience different patterns of DNA methylation and chromatin modifications, thus affecting gene expression in adolescence and adulthood [103]. Recent studies have revealed that monozygotic twins can have significantly different epigenetic status in genes that have been implicated in psychiatric disorders, specifically DRD4 (which encodes
D4 subtype of the dopamine receptor), SLC6A4, and $M A O A$ (which encodes monoamine oxidase $\mathrm{A}$, an enzyme that deaminates dopamine and serotonin) as early as ages 5 to 10 years [104]. Epigenetic differences could therefore be one reason for monozygotic twin discordance in schizophrenia [74,101].

Epigenetic variations could also be partly explained by differences in DNA sequence, such as SNPs and CNVs $[100,105,106]$. For example, Numata et al. [100] reported 
more DNA methylation in one allele of $H L A-D Q B 1$ (which encodes a part of human leukocyte antigen class II molecules, with important functions in the immune system) that contained a SNP (rs1063355) than in the other allele in human postmortem prefrontal cortex samples.

In addition to genetic and environmental factors, Petronis argued that epigenetic status, especially DNA methylation, could also be altered by chance [107]. This stochasticity of changes in DNA methylation might also contribute to epigenetic variation and might be an important factor in complex diseases such as schizophrenia.

Among human tissues, the brain has a particularly complex anatomical structure with functionally different subregions. Epigenetic differences have been reported across different brain subregions [108]. However, it remains unclear which specific subregions are involved in the pathophysiology of schizophrenia, and there is study bias for regions of the frontal cortex and hippocampus, because these regions have been well characterized in previous research. As well as epigenetic differences at the subregion level, each subregion contains various differentiated cells such as neurons and glia. Extensive transcriptome analyses have revealed that each of these cell types has unique expression profiles $[109,110]$, implicating the presence of distinct gene regulation, a large part of which could be attributable to epigenetic mechanisms. Using postmortem brain tissues, neuronal and nonneuronal nuclei can be separated by cell sorting based on NeuN, a neuronal marker $[111,112]$. Recently, oligodendrocyte nuclei were also successfully separated from other non-neuronal nuclei, using an anti-Olig2-antibody [113]. DNA extracted from the separated fractions can be used for epigenetic analysis of histone modifications and DNA methylation [114,115]. Interestingly, studies of neurons have shown not only unique DNA methylation signatures, but also higher interindividual variation compared to non-neurons [114]. These results suggest that neurons might be more susceptible to epigenetic variations due to environmental factors.

Even analyses at the cell-population level may not fully resolve the epigenetic complexity in the brain, because neurons and glia can be further divided into numerous cell types, and each cell type might have a different epigenetic profile. Although laser-assisted microdissection can be useful when analyzing particular cells, other techniques will be required to analyze the epigenome at the single cell level. Recently, Navin et al. [116] quantified genomic CNVs in a single nucleus by whole-genome amplification followed by next-generation sequencing of flow-sorted nuclei, and Bendall et al. [117] reported the results of single-cell mass cytometry. Furthermore, Kantlehner et al. [118] presented a candidate method for single-cell DNA methylation analysis utilizing methylation sensitive restriction enzymes and PCR amplification.
Variation in the epigenome between tissues and cells represents an enormous challenge in epigenetic studies of schizophrenia. Considering that the human brain consists of a larger number of glial cells compared with neuronal cells, it will be necessary to separate distinct cell populations as much as possible when analyzing epigenetic status in brain samples.

\section{Transgenerational epigenetic inheritance}

DNA methylation can be faithfully transmitted from a mother cell to daughter cells during mitosis [119], but a long-standing question is whether transgenerational transmission occurs during the generation of offspring [120].

Mammalian germ-cell-derived DNA is thought to be fully demethylated in early embryos and in primordial germ cells [87]. However, several recent reports have argued that some epigenetic marks survive in early embryos and remain until adulthood. Two groups studying mice reported that epigenetic alterations induced by social stress could be transmitted to the next generation $[121,122]$. Another report demonstrated in mice that parental diet could affect metabolism-related epigenetic status of the offspring [123]. Other groups have reported the existence of transgenerational epigenetic inheritance in nematode and fly models $[124,125]$. However, further studies are needed to investigate epigenetic inheritance in humans. If epigenetic alterations were shown to be transmitted transgenerationally, they could partly explain the heritability of schizophrenia.

\section{Conclusions and future perspectives}

Given that epigenetic status, including DNA methylation and chromatin/histone modifications, affects gene expression, epigenetic alterations could result in functional deficits in brain cells in schizophrenia. Many studies have identified epigenetic alterations in samples obtained from schizophrenia patients, and here we have focused mainly on studies of DNA methylation. However, due to the small sample sizes and technical difficulties, most of the early results were not well replicated [126]. Therefore, the mechanisms underlying the epigenetic alterations in schizophrenia and how these might lead to the symptoms of schizophrenia remain to be understood.

To investigate the importance of previous findings, it will be necessary to perform independent replication studies using larger sample sizes. Most importantly, more comprehensive genome-scale analysis using array-based platforms or next-generation sequencing will be needed [127]. Among these technologies, bisulfite-modified whole-genome sequencing approaches have been utilized for methylome analysis at base pair resolution [35,128]. Recent studies have revealed complex and dynamic patterns of DNA methylation in the human brain. It will 
be important to investigate various cytosine and histone modifications in specific brain cell types to understand their potential roles in the pathophysiology of schizophrenia. Recent technologies that can discriminate between various cytosine modifications on a genomewide scale [90-94] as well as cell-sorting-based analysis [113-115] will empower further characterization of cytosine modifications in brain samples of schizophrenia patients.

Previous research using human samples has shown only associations between specific epigenetic changes and schizophrenia, so it remains unclear whether the identified epigenetic alterations are the causes or the results of schizophrenia pathology. Several groups have reported changes in gene expression associated with epigenetic alterations, but further studies are needed to examine these relationships. After careful and extensive replication studies, the relationship between candidate epigenetic alterations and schizophrenia pathology must be validated using cellular and animal models. Methods for site-specific epigenetic engineering could be used to investigate causality $[129,130]$, although these technologies are still immature. If causality between epigenetic alterations and schizophrenia was demonstrated, therapeutic drugs could be developed by searching for molecules affecting the target epigenetic alterations [40].

In conclusion, despite many challenges regarding the approaches for sampling and detection of epigenetic alterations, epigenetic studies are expected to contribute to our understanding of the pathophysiology of schizophrenia and should provide novel opportunities for the development of therapeutic drugs.

\section{Abbreviations}

acH3, acetylated histone $\mathrm{H} 3$; $\mathrm{acH} 4$, acetylated histone $\mathrm{H} 4$; CNV, copy number variation; DNMT, DNA methyltransferase; $G \times E$, gene-environment interaction; GABA, $\gamma$-aminobutyric acid; $\mathrm{H} 3 \mathrm{~K} 27 \mathrm{me}$, trimethylated lysine 27 of histone $\mathrm{H3}$; $\mathrm{H} 3 \mathrm{~K} 4 \mathrm{me} 3$, trimethylated lysine 4 of histone $\mathrm{H} 3 ; \mathrm{H} 3 \mathrm{~K} 9 \mathrm{~K} 14$, lysine 9/14 of histone $\mathrm{H3}$; HDAC, histone deacetylase; MBD, methyl-CpGbinding domain; MeCP2, methyl-CpG-binding protein 2; MHC, major histocompatibility complex; NMDA, $N$-methyl-D-aspartate; SNP, single nucleotide polymorphism; TET, ten-eleven translocation; VPA, valproate; $5 \mathrm{caC}$, 5-carboxylcytosine; 5fC, 5-formylcytosine; 5hmC, 5-hydroxymethylcytosine; 5hmU, 5-hydroxymethyluracil; 5mC, 5-methylcytosine.

\section{Competing interests}

The authors declare that they have no competing interests.

\section{Acknowledgements}

This work was partly supported by funding for research (Development of biomarker candidates for social behavior) carried out under the Strategic Research Program for Brain Sciences and Grant-in-Aid for Scientific Research on Innovative Areas (Unraveling the micro-endophenotypes of psychiatric disorders at the molecular, cellular and circuit levels) from the Ministry of Education, Culture, Sports, Science and Technology of Japan.

\section{Author details}

'Department of Neuropsychiatry, Graduate School of Medicine, The University of Tokyo, Hongo 7-3-1, Bunkyo-ku, Tokyo 1138655, Japan. ${ }^{2}$ Department of Molecular Psychiatry, Graduate School of Medicine, The University of Tokyo, Hongo 7-3-1, Bunkyo-ku, Tokyo 1138655, Japan. ${ }^{3}$ PRESTO, Japan Science and Technology Agency, 4-1-8, Honcho, Kawaguchi-shi, Saitama 332-0012, Japan.
Published: 13 December 2012

\section{References}

1. Insel TR: Rethinking schizophrenia. Nature 2010, 468:187-193.

2. Prince M, Patel V, Saxena S, Maj M, Maselko J, Phillips M, Rahman A: No health without mental health. Lancet 2007, 370:859-877.

3. Gottesman II: Schizophrenia Genesis: The Origins of Madness. New York: WH Freeman \& Co.; 1991.

4. Brown AS, Derkits EJ: Prenatal infection and schizophrenia: a review of epidemiologic and translational studies. Am J Psychiatry 2010, 167:261-280.

5. Perrin MC, Brown AS, Malaspina D: Aberrant epigenetic regulation could explain the relationship of paternal age to schizophrenia. Schizophr Bull 2007, 33:1270-1273.

6. Susser E, St Clair D, He L: Latent effects of prenatal malnutrition on adult health: the example of schizophrenia. Ann N Y Acad Sci 2008, 1136:185-192.

7. Kunugi H, Nanko S, Murray RM: Obstetric complications and schizophrenia: prenatal underdevelopment and subsequent neurodevelopmental impairment. Br J Psychiatry 2001, 40:s25-29.

8. van Winkel R, Stefanis NC, Myin-Germeys I: Psychosocial stress and psychosis. A review of the neurobiological mechanisms and the evidence for gene-stress interaction. Schizophr Bull 2008, 34:1095-1105.

9. Kelly BD, O'Callaghan E, Waddington JL, Feeney L, Browne S, Scully PJ, Clarke M, Quinn JF, McTigue O, Morgan MG, Kinsella A, Larkin C: Schizophrenia and the city: A review of literature and prospective study of psychosis and urbanicity in Ireland. Schizophr Res 2010, 116:75-89.

10. Cantor-Graae E, Selten JP: Schizophrenia and migration: a meta-analysis and review. Am J Psychiatry 2005, 162:12-24.

11. Davies G, Welham J, Chant D, Torrey EF, McGrath J: A systematic review and meta-analysis of Northern Hemisphere season of birth studies in schizophrenia. Schizophr Bull 2003, 29:587-593.

12. Henquet C, Di Forti M, Morrison P, Kuepper R, Murray RM: Gene-environment interplay between cannabis and psychosis. Schizophr Bull 2008, 34:1111-1121.

13. Clarke MC, Tanskanen A, Huttunen M, Whittaker JC, Cannon M: Evidence for an interaction between familial liability and prenatal exposure to infection in the causation of schizophrenia. Am J Psychiatry 2009, 166:1025-1030.

14. Badner JA, Gershon ES: Meta-analysis of whole-genome linkage scans of bipolar disorder and schizophrenia. Mol Psychiatry 2002, 7:405-411.

15. Harrison PJ, Weinberger DR: Schizophrenia genes, gene expression, and neuropathology: on the matter of their convergence. Mol Psychiatry 2005, 10:40-68.

16. Lewis CM, Levinson DF, Wise LH, DeLisi LE, Straub RE, Hovatta I, Williams NM, Schwab SG, Pulver AE, Faraone SV, Brzustowicz LM, Kaufmann CA, Garver DL, Gurling HM, Lindholm E, Coon H, Moises HW, Byerley W, Shaw SH, Mesen A, Sherrington R, O'Neill FA, Walsh D, Kendler KS, Ekelund J, Paunio T, Lönnqvist J, Peltonen L, O'Donovan MC, Owen MJ, et al:: Genome scan meta-analysis of schizophrenia and bipolar disorder, part II: Schizophrenia. Am J Hum Genet 2003, 73:34-48.

17. Munafo MR, Thiselton DL, ClarkTG, Flint J: Association of the NRG1 gene and schizophrenia: a meta-analysis. Mol Psychiatry 2006, 11:539-546.

18. Ng MY, Levinson DF, Faraone SV, Suarez BK, DeLisi LE, Arinami T, Riley B, Paunio T, Pulver AE, Irmansyah, Holmans PA, Escamilla M, Wildenauer DB, Williams NM, Laurent C, Mowry BJ, Brzustowicz LM, Maziade M, Sklar P, Garver DL, Abecasis GR, Lerer B, Fallin MD, Gurling HM, Gejman PV, Lindholm E, Moises HW, Byerley W, Wijsman EM, Forabosco P, et al:: Meta-analysis of 32 genome-wide linkage studies of schizophrenia. Mol Psychiatry 2009, 14:774-785.

19. O'Donovan MC, Craddock N, Norton N, Williams H, Peirce T, Moskvina V, Nikolov I, Hamshere M, Carroll L, Georgieva L, Dwyer S, Holmans P, Marchini JL, Spencer CC, Howie B, Leung HT, Hartmann AM, Möller HJ, Morris DW, Shi Y, Feng G, Hoffmann P, Propping P, Vasilescu C, Maier W, Rietschel M, Zammit S, Schumacher J, Quinn EM, Schulze TG, et al.: Identification of loci associated with schizophrenia by genome-wide association and follow-up. Nat Genet 2008, 40:1053-1055.

20. Purcell SM, Wray NR, Stone JL, Visscher PM, O'Donovan MC, Sullivan PF, Sklar $\mathrm{P}$ : Common polygenic variation contributes to risk of schizophrenia and bipolar disorder. Nature 2009, 460:748-752.

21. Schizophrenia Psychiatric Genome-Wide Association Study (GWAS) Consortium: Genome-wide association study identifies five new schizophrenia loci. Nat Genet 2011, 43:969-976.

22. Shi J, Levinson DF, Duan J, Sanders AR, Zheng Y, Pe'er I, Dudbridge F, Holmans 
PA, Whittemore AS, Mowry BJ, Olincy A, Amin F, Cloninger CR, Silverman JM, Buccola NG, Byerley WF, Black DW, Crowe RR, Oksenberg JR, Mirel DB, Kendler KS, Freedman R, Gejman PV: Common variants on chromosome 6p22.1 are associated with schizophrenia. Nature 2009, 460:753-757.

23. Stefansson H, Ophoff RA, Steinberg S, Andreassen OA, Cichon S, Rujescu D, Werge T, Pietilainen OP, Mors O, Mortensen PB, Olincy A, Amin F, Cloninger CR, Silverman JM, Buccola NG, Byerley WF, Black DW, Crowe RR, Oksenberg JR, Mirel DB, Kendler KS, Freedman R, Gejman PV: Common variants conferring risk of schizophrenia. Nature 2009, 460:744-747.

24. Bassett AS, Scherer SW, Brzustowicz LM: Copy number variations in schizophrenia: critical review and new perspectives on concepts of genetics and disease. Am J Psychiatry 2010, 167:899-914.

25. Stefansson H, Rujescu D, Cichon S, Pietilainen OP, Ingason A, Steinberg S, Fossdal R, Sigurdsson E, Sigmundsson T, Buizer-Voskamp JE, Hansen T, Jakobsen KD, Muglia P, Francks C, Matthews PM, Gylfason A, Halldorsson BV, Gudbjartsson D, Thorgeirsson TE, Sigurdsson A, Jonasdottir A, Jonasdottir A, Bjornsson A, Mattiasdottir S, Blondal T, Haraldsson M, Magnusdottir BB, Giegling I, Möller HJ, Hartmann A, et al:: Large recurrent microdeletions associated with schizophrenia. Nature 2008, 455:232-236.

26. International Schizophrenia Consortium: Rare chromosomal deletions and duplications increase risk of schizophrenia. Nature 2008, 455:237-241.

27. Sullivan PF, Daly MJ, O'Donovan M: Genetic architectures of psychiatric disorders: the emerging picture and its implications. Nat Rev Genet 2012, 13:537-551.

28. Karayiorgou M, Simon TJ, Gogos JA: 22q11.2 microdeletions: linking DNA structural variation to brain dysfunction and schizophrenia. Nat Rev Neurosci 2010, 11:402-416.

29. McCarthy SE, Makarov V, Kirov G, Addington AM, McClellan J, Yoon S, Perkins DO, Dickel DE, Kusenda M, Krastoshevsky O, Krause V, Kumar RA, Grozeva D, Malhotra D, Walsh T, Zackai EH, Kaplan P, Ganesh J, Krantz ID, Spinner NB, Roccanova P, Bhandari A, Pavon K, Lakshmi B, Leotta A, Kendall J, Lee YH, Vacic V, Gary S, lakoucheva LM, et al: Microduplications of 16p11.2 are associated with schizophrenia. Nat Genet 2009, 41:1223-1227.

30. Kirov G, Pocklington AJ, Holmans P, Ivanov D, Ikeda M, Ruderfer D, Moran J, Chambert K, Toncheva D, Georgieva L, Grozeva D, Fjodorova M, Wollerton R, Rees E, Nikolov I, van de Lagemaat LN, Bayés A, Fernandez E, Olason PI, Böttcher Y, Komiyama NH, Collins MO, Choudhary J, Stefansson K, Stefansson H, Grant SG, Purcell S, Sklar P, O'Donovan MC, Owen MJ: De novo CNV analysis implicates specific abnormalities of postsynaptic signalling complexes in the pathogenesis of schizophrenia. Mol Psychiatry 2012, 17:142-153

31. Pidsley R, Mill J: Epigenetic studies of psychosis: current findings, methodological approaches, and implications for postmortem research. Biol Psychiatry 2011, 69:146-156.

32. Labrie V, Pai S, Petronis A: Epigenetics of major psychosis: progress, problems and perspectives. Trends Genet 2012, 28:427-435.

33. Bird A: DNA methylation patterns and epigenetic memory. Genes Dev 2002, 16:6-21.

34. Choi JK, Bae JB, Lyu J, Kim TY, Kim YJ: Nucleosome deposition and DNA methylation at coding region boundaries. Genome Bio/ 2009, 10:R89.

35. Maunakea AK, Nagarajan RP, Bilenky M, Ballinger TJ, D'Souza C, Fouse SD, Johnson BE, Hong C, Nielsen C, Zhao Y, Turecki G, Delaney A, Varhol R, Thiessen N, Shchors K, Heine VM, Rowitch DH, Xing X, Fiore C, SchillebeeckX M, Jones SJ, Haussler D, Marra MA, Hirst M, Wang T, Costello JF: Conserved role of intragenic DNA methylation in regulating alternative promoters. Nature 2010, 466:253-257.

36. Jirtle RL, Skinner MK: Environmental epigenomics and disease susceptibility. Nat Rev Genet 2007, 8:253-262.

37. Peter CJ, Akbarian S: Balancing histone methylation activities in psychiatric disorders. Trends Mol Med 2011, 17:372-379.

38. Beveridge NJ, Cairns MJ: MicroRNA dysregulation in schizophrenia. Neurobiol Dis 2012, 46:263-271.

39. Im HI, Kenny PJ: MicroRNAs in neuronal function and dysfunction. Trends Neurosci 2012, 35:325-334

40. Jakovcevski M, Akbarian S: Epigenetic mechanisms in neurological disease. Nat Med 2012, 18:1194-1204

41. Li JZ, Vawter MP, Walsh DM, Tomita H, Evans SJ, Choudary PV, Lopez JF, Avelar A, Shokoohi V, Chung T, Mesarwi O, Jones EG, Watson SJ, Akil H, Bunney WE Jr. Myers RM: Systematic changes in gene expression in postmortem human brains associated with tissue $\mathrm{pH}$ and terminal medical conditions. Hum Mol Genet 2004, 13:609-616.
42. Tomita H, Vawter MP, Walsh DM, Evans SJ, Choudary PV, Li J, Overman KM, Atz ME, Myers RM, Jones EG, Watson SJ, Akil H, Bunney WE Jr: Effect of agonal and postmortem factors on gene expression profile: quality control in microarray analyses of postmortem human brain. Biol Psychiatry 2004, 55:346-352.

43. Iwamoto K, Kato T: Gene expression profiling in schizophrenia and related mental disorders. Neuroscientist 2006, 12:349-361.

44. Ernst C, McGowan PO, Deleva V, Meaney MJ, Szyf M, Turecki G: The effects of $\mathrm{pH}$ on DNA methylation state: In vitro and post-mortem brain studies. J Neurosci Methods 2008, 174:123-125.

45. Guidotti A, Auta J, Davis JM, Di-Giorgi-Gerevini V, Dwivedi Y, Grayson DR, Impagnatiello F, Pandey G, Pesold C, Sharma R, Uzunov D, Costa E: Decrease in reelin and glutamic acid decarboxylase67 (GAD67) expression in schizophrenia and bipolar disorder: a postmortem brain study. Arch Gen Psychiatry 2000, 57:1061-1069.

46. Grayson DR, Jia X, Chen Y, Sharma RP, Mitchell CP, Guidotti A, Costa E: Reelin promoter hypermethylation in schizophrenia. Proc Natl Acad Sci U S A 2005, 102:9341-9346.

47. Guidotti A, Auta J, Chen Y, Davis JM, Dong E, Gavin DP, Grayson DR, Matrisciano F, Pinna G, Satta R, Sharma RP, Tremolizzo L, Tueting P: Epigenetic GABAergic targets in schizophrenia and bipolar disorder. Neuropharmacology 2011, 60:1007-1016.

48. Ruzicka WB, Zhubi A, Veldic M, Grayson DR, Costa E, Guidotti A: Selective epigenetic alteration of layer I GABAergic neurons isolated from prefrontal cortex of schizophrenia patients using laser-assisted microdissection. Mol Psychiatry 2007, 12:385-397.

49. Mill J, Tang T, Kaminsky Z, Khare T, Yazdanpanah S, Bouchard L, Jia P, Assadzadeh A, Flanagan J, Schumacher A, Wang SC, Petronis A: Epigenomic profiling reveals DNA-methylation changes associated with major psychosis. Am J Hum Genet 2008, 82:696-711

50. Tochigi M, Iwamoto K, Bundo M, Komori A, Sasaki T, Kato N, Kato T: Methylation status of the reelin promoter region in the brain of schizophrenic patients. Biol Psychiatry 2008, 63:530-533.

51. Abdolmaleky HM, Cheng KH, Faraone SV, Wilcox M, Glatt SJ, Gao F, Smith CL, Shafa R, Aeali B, Carnevale J, Pan H, Papageorgis P, Ponte JF, Sivaraman V, Tsuang MT, Thiagalingam S: Hypomethylation of MB-COMT promoter is a major risk factor for schizophrenia and bipolar disorder. Hum Mol Genet 2006, 15:3132-3145.

52. Dempster EL, Mill J, Craig IW, Collier DA: The quantification of COMT mRNA in post mortem cerebellum tissue: diagnosis, genotype, methylation and expression. BMC Med Genet 2006, 7:10.

53. Iwamoto K, Bundo M, Yamada K, Takao H, Iwayama-Shigeno Y, Yoshikawa T, Kato T: DNA methylation status of SOX 10 correlates with its downregulation and oligodendrocyte dysfunction in schizophrenia. J Neurosci 2005, 25:5376-5381.

54. Flynn SW, Lang DJ, Mackay AL, Goghari V, Vavasour IM, Whittall KP, Smith GN, Arango V, Mann JJ, Dwork AJ, Falkai P, Honer WG: Abnormalities of myelination in schizophrenia detected in vivo with MRI, and post-mortem with analysis of oligodendrocyte proteins. Mol Psychiatry 2003, 8:811-820

55. Tkachev D, Mimmack ML, Ryan MM, Wayland M, Freeman T, Jones PB, Starkey M, Webster MJ, Yolken RH, Bahn S: Oligodendrocyte dysfunction in schizophrenia and bipolar disorder. Lancet 2003, 362:798-805

56. Tolosa A, Sanjuan J, Dagnall AM, Molto MD, Herrero N, de Frutos R: FOXP2 gene and language impairment in schizophrenia: association and epigenetic studies. BMC Med Genet 2010, 11:114.

57. Abdolmaleky HM, Yaqubi S, Papageorgis P, Lambert AW, Ozturk S, Sivaraman $\mathrm{V}$, Thiagalingam S: Epigenetic dysregulation of HTR2A in the brain of patients with schizophrenia and bipolar disorder. Schizophr Res 2011, 129:183-190.

58. Akbarian S, Ruehl MG, Bliven E, Luiz LA, Peranelli AC, Baker SP, Roberts RC, Bunney WE, Jr, Conley RC, Jones EG, Tamminga CA, Guo Y: Chromatin alterations associated with down-regulated metabolic gene expression in the prefrontal cortex of subjects with schizophrenia. Arch Gen Psychiatry 2005, 62:829-840.

59. Huang HS, Matevossian A, Whittle C, Kim SY, Schumacher A, Baker SP, Akbarian S: Prefrontal dysfunction in schizophrenia involves mixed-lineage leukemia 1-regulated histone methylation at GABAergic gene promoters. J Neurosci 2007, 27:11254-11262.

60. Tang B, Dean B, Thomas EA: Disease- and age-related changes in histone acetylation at gene promoters in psychiatric disorders. Transl Psychiatry 2011, 1:e64. 
61. Murphy BC, O'Reilly RL, Singh SM: Site-specific cytosine methylation in $\mathrm{S}$-COMT promoter in 31 brain regions with implications for studies involving schizophrenia. Am J Med Genet B Neuropsychiatr Genet 2005, 133B:37-42.

62. Dempster EL, Pidsley R, Schalkwyk LC, Owens S, Georgiades A, Kane F, Kalidindi S, Picchioni M, Kravariti E, Toulopoulou T, Murray RM, Mill J: Diseaseassociated epigenetic changes in monozygotic twins discordant for schizophrenia and bipolar disorder. Hum Mol Genet 2011, 20:4786-4796.

63. Sugawara H, Iwamoto K, Bundo M, Ueda J, Miyauchi T, Komori A, Kazuno A, Adati N, Kusumi I, Okazaki Y, Ishigooka J, Kojima T, Kato T: Hypermethylation of serotonin transporter gene in bipolar disorder detected by epigenome analysis of discordant monozygotic twins. Translational Psychiatry 2011, 1:e24.

64. Kaminsky Z, Tochigi M, Jia P, Pal M, Mill J, Kwan A, loshikhes I, Vincent JB, Kennedy JL, Strauss J, Ishigooka J, Kojima T, Kato T: A multi-tissue analysis identifies HLA complex group 9 gene methylation differences in bipolar disorder. Mol Psychiatry 2012, 17:728-740.

65. Davies MN, Volta M, Pidsley R, Lunnon K, Dixit A, Lovestone S, Coarfa C, Harris RA, Milosavljevic A, Troakes C, Al-Sarraj S, Dobson R, Schalkwyk LC, Mill J: Functional annotation of the human brain methylome identifies tissuespecific epigenetic variation across brain and blood. Genome Biol 2012, 13:R43.

66. Shimabukuro M, Sasaki T, Imamura A, Tsujita T, Fuke C, Umekage T, Tochigi M Hiramatsu K, Miyazaki T, Oda T, Sugimoto J, Jinno Y, Okazaki Y: Global hypomethylation of peripheral leukocyte DNA in male patients with schizophrenia: a potential link between epigenetics and schizophrenia. J Psychiatr Res 2007, 41:1042-1046.

67. Melas PA, Rogdaki M, Osby U, Schalling M, Lavebratt C, Ekstrom TJ: Epigenetic aberrations in leukocytes of patients with schizophrenia: association of global DNA methylation with antipsychotic drug treatment and disease onset. FASEB J 2012, 26:2712-2718.

68. Bromberg A, Levine J, Nemetz B, Belmaker RH, Agam G: No association between global leukocyte DNA methylation and homocysteine levels in schizophrenia patients. Schizophr Res 2008, 101:50-57.

69. Zhubi A, Veldic M, Puri NV, Kadriu B, Caruncho H, Loza I, Sershen H, Lajtha A, Smith RC, Guidotti A, Davis JM, Costa E: An upregulation of DNAmethyltransferase 1 and 3a expressed in telencephalic GABAergic neurons of schizophrenia patients is also detected in peripheral blood lymphocytes. Schizophr Res 2009, 111:115-122.

70. Carrard A, Salzmann A, Malafosse A, Karege F: Increased DNA methylation status of the serotonin receptor 5 HTR1A gene promoter in schizophrenia and bipolar disorder. J Affect Disord 2011, 132:450-453.

71. Pun FW, Zhao C, Lo WS, Ng SK, Tsang SY, Nimgaonkar V, Chung WS, Ungvari $G S$, Xue H: Imprinting in the schizophrenia candidate gene GABRB2 encoding GABA(A) receptor beta(2) subunit. Mol Psychiatry 2011 , 16:557-568.

72. Ghadirivasfi M, Nohesara S, Ahmadkhaniha HR, Eskandari MR, Mostafavi S, Thiagalingam S, Abdolmaleky HM: Hypomethylation of the serotonin receptor type-2A Gene (HTR2A) at T102C polymorphic site in DNA derived from the saliva of patients with schizophrenia and bipolar disorder. Am J Med Genet B Neuropsychiatr Genet 2011, 156:536-545.

73. Nohesara S, Ghadirivasfi M, Mostafavi S, Eskandari MR, Ahmadkhaniha H, Thiagalingam S, Abdolmaleky HM: DNA hypomethylation of MB-COMT promoter in the DNA derived from saliva in schizophrenia and bipolar disorder. J Psychiatr Res 2011, 45:1432-1438.

74. Petronis A, Gottesman, II, Kan P, Kennedy JL, Basile VS, Paterson AD, Popendikyte V: Monozygotic twins exhibit numerous epigenetic differences: clues to twin discordance? Schizophr Bull 2003, 29:169-178.

75. Kano S, Colantuoni C, Han F, Zhou Z, Yuan Q, Wilson A, Takayanagi Y, Lee Y, Rapoport J, Eaton W, Cascella N, Ji H, Goldman D, Sawa A: Genome-wide profiling of multiple histone methylations in olfactory cells: further implications for cellular susceptibility to oxidative stress in schizophrenia. Mol Psychiatry 2012. doi:10.1038/mp.2012.120.

76. Weaver IC, Cervoni N, Champagne FA, D'Alessio AC, Sharma S, SeckI JR, Dymov S, Szyf M, Meaney MJ: Epigenetic programming by maternal behavior. Nat Neurosci 2004, 7:847-854.

77. Dong E, Agis-Balboa RC, Simonini MV, Grayson DR, Costa E, Guidotti A: Reelin and glutamic acid decarboxylase 67 promoter remodeling in an epigenetic methionine-induced mouse model of schizophrenia. Proc Natl Acad SciU S A 2005, 102:12578-12583.

78. Tremolizzo L, Doueiri MS, Dong E, Grayson DR, Davis J, Pinna G, Tueting P,
Rodriguez-Menendez V, Costa E, Guidotti A: Valproate corrects the schizophrenia-like epigenetic behavioral modifications induced by methionine in mice. Biol Psychiatry 2005, 57:500-509.

79. Sharma RP, Rosen C, Kartan S, Guidotti A, Costa E, Grayson DR, Chase K: Valproic acid and chromatin remodeling in schizophrenia and bipolar disorder: preliminary results from a clinical population. Schizophr Res 2006 88:227-231.

80. Gavin DP, Kartan S, Chase K, Grayson DR, Sharma RP: Reduced baseline acetylated histone 3 levels, and a blunted response to HDAC inhibition in lymphocyte cultures from schizophrenia subjects. Schizophr Res 2008, 103:330-332.

81. Gavin DP, Rosen C, Chase K, Grayson DR, Tun N, Sharma RP: Dimethylated lysine 9 of histone 3 is elevated in schizophrenia and exhibits a divergent response to histone deacetylase inhibitors in lymphocyte cultures. J Psychiatry Neurosci 2009, 34:232-237.

82. Gavin DP, Kartan S, Chase K, Jayaraman S, Sharma RP: Histone deacetylase inhibitors and candidate gene expression: An in vivo and in vitro approach to studying chromatin remodeling in a clinical population. J Psychiatr Res 2009, 43:870-876.

83. Kriaucionis $\mathrm{S}$, Heintz $\mathrm{N}$ : The nuclear DNA base 5 -hydroxymethylcytosine is present in Purkinje neurons and the brain. Science 2009, 324:929-930.

84. Tahiliani M, Koh KP, Shen Y, Pastor WA, Bandukwala H, Brudno Y, Agarwal S, lyer LM, Liu DR, Aravind L, Rao A: Conversion of 5-methylcytosine to 5-hydroxymethylcytosine in mammalian DNA by MLL partner TET1. Science 2009, 324:930-935.

85. Cortellino S, Xu J, Sannai M, Moore R, Caretti E, Cigliano A, Le Coz M, Devarajan K, Wessels A, Soprano D, Abramowitz LK, Bartolomei MS, Rambow F, Bassi MR, Bruno T, Fanciulli M, Renner C, Klein-Szanto AJ, Matsumoto Y, Kob D, Davidson I, Alberti C, Larue L, Bellacosa A: Thymine DNA glycosylase is essential for active DNA demethylation by linked deamination-base excision repair. Cell 2011, 146:67-79.

86. Guo JU, Su Y, Zhong C, Ming GL, Song H: Hydroxylation of 5-methylcytosine by TET1 promotes active DNA demethylation in the adult brain. Cell 2011, 145:423-434.

87. Popp C, Dean W, Feng S, Cokus SJ, Andrews S, Pellegrini M, Jacobsen SE, Reik W: Genome-wide erasure of DNA methylation in mouse primordial germ cells is affected by AID deficiency. Nature 2010, 463:1101-1105.

88. Ito S, Shen L, Dai Q, Wu SC, Collins LB, Swenberg JA, He C, Zhang Y: Tet proteins can convert 5 -methylcytosine to 5 -formylcytosine and 5-carboxylcytosine. Science 2011, 333:1300-1303.

89. He YF, Li BZ, Li Z, Liu P, Wang Y, Tang Q, Ding J, Jia Y, Chen Z, Li L, Sun Y, Li X, Dai Q, Song CX, Zhang K, He C, Xu GL: Tet-mediated formation of 5-carboxylcytosine and its excision by TDG in mammalian DNA. Science 2011, 333:1303-1307.

90. Flusberg BA, Webster DR, Lee JH, Travers KJ, Olivares EC, Clark TA, Korlach J, Turner SW: Direct detection of DNA methylation during single-molecule, real-time sequencing. Nat Methods 2010, 7:461-465.

91. Song CX, Clark TA, Lu XY, Kislyuk A, Dai Q, Turner SW, He C, Korlach J: Sensitive and specific single-molecule sequencing of 5-hydroxymethylcytosine. Nat Methods 2011, 9:75-77.

92. Song CX, Szulwach KE, Fu Y, Dai Q, Yi C, Li X, Li Y, Chen CH, Zhang W, Jian X Wang J, Zhang L, Looney TJ, Zhang B, Godley LA, Hicks LM, Lahn BT, Jin P, He C: Selective chemical labeling reveals the genome-wide distribution of 5-hydroxymethylcytosine. Nat Biotechnol 2011, 29:68-72.

93. Robertson AB, Dahl JA, Ougland R, Klungland A: Pull-down of 5-hydroxymethylcytosine DNA using JBP1-coated magnetic beads. Nat Protoc 2012, 7:340-350

94. Booth MJ, Branco MR, Ficz G, Oxley D, Krueger F, Reik W, Balasubramanian S: Quantitative sequencing of 5-methylcytosine and 5-hydroxymethylcytosine at single-base resolution. Science 2012, 336:934-937.

95. Bjornsson HT, Sigurdsson MI, Fallin MD, Irizarry RA, Aspelund T, Cui H, Yu W, Rongione MA, Ekstrom TJ, Harris TB, Launer LJ, Eiriksdottir G, Leppert MF, Sapienza C, Gudnason V, Feinberg AP: Intra-individual change over time in DNA methylation with familial clustering. JAMA 2008, 299:2877-2883.

96. Christensen BC, Houseman EA, Marsit CJ, Zheng S, Wrensch MR, Wiemels JL, Nelson HH, Karagas MR, Padbury JF, Bueno R, Sugarbaker DJ, Yeh RF, Wiencke $J \mathrm{~K}$, Kelsey KT: Aging and environmental exposures alter tissue-specific DNA methylation dependent upon CpG island context. PLoS Genet 2009, 5:e1000602

97. Flanagan JM, Popendikyte V, Pozdniakovaite N, Sobolev M, Assadzadeh A, 
Schumacher A, Zangeneh M, Lau L, Virtanen C, Wang SC, Petronis A: Intraand interindividual epigenetic variation in human germ cells. Am J Hum Genet 2006, 79:67-84

98. Hernandez DG, Nalls MA, Gibbs JR, Arepalli S, van der Brug M, Chong S, Moore M, Longo DL, Cookson MR, Traynor BJ, Singleton AB: Distinct DNA methylation changes highly correlated with chronological age in the human brain. Hum Mol Genet 2011, 20:1 164-1172.

99. Heyn H, Li N, Ferreira HJ, Moran S, Pisano DG, Gomez A, Diez J, Sanchez-Mut JV, Setien F, Carmona FJ, Puca AA, Sayols S, Pujana MA, Serra-Musach J, Iglesias-Platas I, Formiga F, Fernandez AF, Fraga MF, Heath SC, Valencia A, Gut IG, Wang J, Esteller M: Distinct DNA methylomes of newborns and centenarians. Proc Natl Acad Sci U S A 2012, 109:10522-10527.

100. Numata S, Ye T, Hyde TM, Guitart-Navarro X, Tao R, Wininger M, Colantuoni C, Weinberger DR, Kleinman JE, Lipska BK: DNA methylation signatures in development and aging of the human prefrontal cortex. Am $\mathrm{J}$ Hum Genet 2012, 90:260-272.

101. Kato T, Iwamoto K, Kakiuchi C, Kuratomi G, Okazaki Y: Genetic or epigenetic difference causing discordance between monozygotic twins as a clue to molecular basis of mental disorders. Mol Psychiatry 2005, 10:622-630.

102. Kaminsky ZA, Tang T, Wang SC, Ptak C, Oh GH, Wong AH, Feldcamp LA, Virtanen C, Halfvarson J, Tysk C, McRae AF, Visscher PM, Montgomery GW, Gottesman II, Martin NG, Petronis A: DNA methylation profiles in monozygotic and dizygotic twins. Nat Genet 2009, 41:240-245.

103. Fraga MF, Ballestar E, Paz MF, Ropero S, Setien F, Ballestar ML, Heine-Suner D, Cigudosa JC, Urioste M, Benitez J, Boix-Chornet M, Sanchez-Aguilera A, Ling C, Carlsson E, Poulsen P, Vaag A, Stephan Z, Spector TD, Wu YZ, Plass C, Esteller M: Epigenetic differences arise during the lifetime of monozygotic twins. Proc Natl Acad Sci U S A 2005, 102:10604-10609.

104. Wong CC, Caspi A, Williams B, Craig IW, Houts R, Ambler A, Moffitt TE, Mill J: A longitudinal study of epigenetic variation in twins. Epigenetics 2010, 5:516-526.

105. Gertz J, Varley KE, Reddy TE, Bowling KM, Pauli F, Parker SL, Kucera KS, Willard $H F$, Myers RM: Analysis of DNA methylation in a three-generation family reveals widespread genetic influence on epigenetic regulation. PLoS Genet 2011, 7:e1002228.

106. Zhang D, Cheng L, Badner JA, Chen C, Chen Q, Luo W, Craig DW, Redman M, Gershon ES, Liu C: Genetic control of individual differences in gene-specific methylation in human brain. Am J Hum Genet 2010, 86:411-419.

107. Petronis A: Epigenetics as a unifying principle in the aetiology of complex traits and diseases. Nature 2010, 465:721-727.

108. Ladd-Acosta C, Pevsner J, Sabunciyan S, Yolken RH, Webster MJ, Dinkins T, Callinan PA, Fan JB, Potash JB, Feinberg AP: DNA methylation signatures within the human brain. Am J Hum Genet 2007, 81:1304-1315.

109. Cahoy JD, Emery B, Kaushal A, Foo LC, Zamanian JL, Christopherson KS, Xing Y, Lubischer JL, Krieg PA, Krupenko SA, Thompson WJ, Barres BA: A transcriptome database for astrocytes, neurons, and oligodendrocytes: a new resource for understanding brain development and function. J Neurosci 2008, 28:264-278.

110. Sugino K, Hempel CM, Miller MN, Hattox AM, Shapiro P, Wu C, Huang ZJ, Nelson SB: Molecular taxonomy of major neuronal classes in the adult mouse forebrain. Nat Neurosci 2006, 9:99-107.

111. Rehen SK, Yung YC, McCreight MP, Kaushal D, Yang AH, Almeida BS, Kingsbury MA, Cabral KM, McConnell MJ, Anliker B, Fontanoz M, Chun J: Constitutional aneuploidy in the normal human brain. J Neurosci 2005, 25:2176-2180.

112. Spalding KL, Bhardwaj RD, Buchholz BA, Druid H, Frisen J: Retrospective birth dating of cells in humans. Cell 2005, 122:133-143.

113. Hayashi Y, Nihonmatsu-Kikuchi N, Yu X, Ishimoto K, Hisanaga SI, Tatebayashi Y: A novel, rapid, quantitative cell-counting method reveals oligodendroglial reduction in the frontopolar cortex in major depressive disorder. $\mathrm{Mol}$ Psychiatry 2011, 16:1155-1158.

114. I wamoto K, Bundo M, Ueda J, Oldham MC, Ukai W, Hashimoto E, Saito T, Geschwind DH, Kato T: Neurons show distinctive DNA methylation profile and higher interindividual variations compared with non-neurons. Genome Res 2011, 21:688-696.

115. Siegmund KD, Connor CM, Campan M, Long TI, Weisenberger DJ, Biniszkiewicz D, Jaenisch R, Laird PW, Akbarian S: DNA methylation in the human cerebral cortex is dynamically regulated throughout the life span and involves differentiated neurons. PLoS One 2007, 2:e895.

116. Navin N, Kendall J, Troge J, Andrews P, Rodgers L, Mclndoo J, Cook K, Stepansky A, Levy D, Esposito D, Muthuswamy L, Krasnitz A, McCombie WR, Hicks J, Wigler M: Tumour evolution inferred by single-cell sequencing. Nature 2011, 472:90-94.

117. Bendall SC, Simonds EF, Qiu P, Amir el AD, Krutzik PO, Finck R, Bruggner RV, Melamed R, Trejo A, Ornatsky OI, Balderas RS, Plevritis SK, Sachs K, Pe'er D, Tanner SD, Nolan GP: Single-cell mass cytometry of differential immune and drug responses across a human hematopoietic continuum. Science 2011, 332:687-696.

118. Kantlehner M, Kirchner R, Hartmann P, Ellwart JW, Alunni-Fabbroni M, Schumacher A: A high-throughput DNA methylation analysis of a single cell. Nucleic Acids Res 2011, 39:e44.

119. Ushijima T, Watanabe N, Okochi E, Kaneda A, Sugimura T, Miyamoto K: Fidelity of the methylation pattern and its variation in the genome. Genome Res 2003, 13:868-874.

120. Daxinger $L$, Whitelaw $E$ : Understanding transgenerational epigenetic inheritance via the gametes in mammals. Nat Rev Genet 2012, 13:153-162.

121. Dietz DM, Laplant Q, Watts EL, Hodes GE, Russo SJ, Feng J, Oosting RS, Vialou V, Nestler EJ: Paternal transmission of stress-induced pathologies. Biol Psychiatry 2011, 70:408-414

122. Franklin TB, Russig H, Weiss IC, Graff J, Linder N, Michalon A, Vizi S, Mansuy IM: Epigenetic transmission of the impact of early stress across generations. Biol Psychiatry 2010, 68:408-415.

123. Carone BR, Fauquier L, Habib N, Shea JM, Hart CE, Li R, Bock C, Li C, Gu H, Zamore PD, Meissner A, Weng Z, Hofmann HA, Friedman N, Rando OJ: Paternally induced transgenerational environmental reprogramming of metabolic gene expression in mammals. Cell 2010, 143:1084-1096.

124. Greer EL, Maures TJ, Ucar D, Hauswirth AG, Mancini E, Lim JP, Benayoun BA, Shi Y, Brunet A: Transgenerational epigenetic inheritance of longevity in Caenorhabditis elegans. Nature 2011, 479:365-371.

125. Seong KH, Li D, Shimizu H, Nakamura R, Ishii S: Inheritance of stress-induced, ATF-2-dependent epigenetic change. Cell 2011, 145:1049-1061.

126. Iwamoto K, Kato T: Epigenetic profiling in schizophrenia and major mental disorders. Neuropsychobiology 2009, 60:5-11.

127. Rakyan VK, Down TA, Balding DJ, Beck S: Epigenome-wide association studies for common human diseases. Nat Rev Genet 2011, 12:529-541.

128. Lister R, Pelizzola M, Dowen RH, Hawkins RD, Hon G, Tonti-Filippini J, Nery JR, Lee L, Ye Z, Ngo QM, Edsall L, Antosiewicz-Bourget J, Stewart R, Ruotti V, Millar AH, Thomson JA, Ren B, Ecker JR: Human DNA methylomes at base resolution show widespread epigenomic differences. Nature 2009, 462:315-322.

129. Li F, Papworth M, Minczuk M, Rohde C, Zhang Y, Ragozin S, Jeltsch A: Chimeric DNA methyltransferases target DNA methylation to specific DNA sequences and repress expression of target genes. Nucleic Acids Res 2007, 35:100-112.

130. Smith $A E$, Ford KG: Specific targeting of cytosine methylation to DNA sequences in vivo. Nucleic Acids Res 2007, 35:740-754

131. Nabel CS, Jia H, Ye Y, Shen L, Goldschmidt HL, Stivers JT, Zhang Y, Kohli RM: AID/APOBEC deaminases disfavor modified cytosines implicated in DNA demethylation. Nat Chem Biol 2012, 8:751-758.

doi:10.1186/gm397

Cite this article as: Nishioka M, et al.: DNA methylation in schizophrenia: progress and challenges of epigenetic studies. Genome Medicine 2012, 4:96. 